\title{
Experiments in Life-Writing: Introduction
}

\author{
Julia Novak
}

Other people's life stories fascinate us, and we seem to have an urgent need to record these stories. As writers continue to experiment with the formal and aesthetic possibilities of rendering their subjects' lives in ever new ways, the modes of writing about historical lives have diversified enormously, and continue to do so. The proliferation of public interest in accounts of historical lives in recent decades-captured by such buzzwords as "biography boom" or "memoir craze"-is reflected in the similarly expanding field of life-writing studies, as scholars regularly re-conceptualise their object of study to keep pace with the rapid evolution of life-writing forms and to incorporate the new insights their discipline has yielded. Within this context, the term "life-writing" itself has emerged to reflect the diverse work conducted in the field. It has now come to stand for

a range of writings about lives or parts of lives, or which provide materials out of which lives or parts of lives are composed. These writings include not only memoir, autobiography, biography, diaries, autobiographical fiction, and biographical fiction, but also letters, writs, wills, written anecdotes, depositions, court proceedings, ... marginalia, nonce writings, lyric poems, scientific and historical writings, and digital forms. ${ }^{1}$

\section{J. Novak $(\bowtie)$}

University of Salzburg, Erzabt Klotz Strasse 1, 5020 Salzburg, Austria e-mail: Julia.Lajta-Novak@kcl.ac.uk

(C) The Author(s) 2017

L. Boldrini and J. Novak (eds.), Experiments in Life-Writing,

Palgrave Studies in Life Writing,

DOI 10.1007/978-3-319-55414-3_1 
Biography and autobiography - two extensive fields of cultural production and academic research now commonly subsumed under life-writing-have in turn come under scrutiny as scholars have attempted to accommodate newly developing forms and direct our gaze to the manifold guises that writings about "real people" can assume. Thus, in their primer Reading Autobiography (2010), Sidonie Smith and Julia Watson discuss the limitations of the term "autobiography" for contemporary scholarship - its politics of exclusion as regards, for instance, ethnic identity. Following Julie Rak and Leigh Gilmore, Smith and Watson propose a shift from autobiography as genre to "autobiographical discourse," using the adjective to designate "self-referential writing" in a more inclusive manner. ${ }^{2}$ Hermione Lee's revised, very broad definition of "biography" in Biography: A Very Short Introduction (2009) as "the story of a person told by someone else" 3 appears also to pay tribute to the diverse shapes that specific "tellings" can take. However, in common use, the term "biography" is still primarily taken to denote factual cradle-to-grave narratives in book form, while "life-writing," as a loose umbrella term, explicitly encompasses auto/biographical fiction, as Zachary Leader notes in the above definition. That fiction these days habitually registers on the life-writing radar is reflected also by the event programmes and the work conducted at various centres for life-writing research ${ }^{4}$ as well as by the awarding in 2016 of the prestigious Erasmus Prize to novelist A. S. Byatt-for her "inspiring contribution to "life writing." 5

The present essay collection examines "experiments" in life-writings of the twentieth and twenty-first centuries which are located at the intersections of auto/biography and fiction, so as to shed light on the ways in which writers have engaged with, and extended the range of, modern auto/biography. Andrew M. Colman describes experimental methods in the natural sciences as being "uniquely powerful in allowing rigorous examination of causal effects without the uncertainties of other research methods." While for scientists such experimentation may serve to establish certainties, writers have long demonstrated that literary experiments tend to have the opposite effect: they open up alternative and multiple ways of reading and pose new epistemological challenges. ${ }^{7}$

The recent explosion of experimentation in life-writing is testified by the proliferation of genre designations such as "meta-autobiography," "autotopography," "creative non-fiction," "false novel," "autofiction," "biofiction," "auto/biografiction," "autobiographical non-fiction novel," "auto/biographic metafiction," or "heterobiography"-a few 
of the forms considered in this volume. Such generic labels attempt to specify the ways in which texts depart from the tenets of traditional biography and autobiography and, more specifically, capture the relationship of fact and fiction and the relations between the writing and written subjects that these texts reconfigure. What all of these forms share, and which is, according to the editors of the Routledge Companion to Experimental Literature, a defining mark of literary experiments in general, is a "commitment to raising fundamental questions about the very nature and being of verbal art itself"-questions which mainstream literature "at all periods . . . is dedicated to repressing." 8

\section{Negating and Expanding the Auto/Biographical Project}

Genre labels such as "auto/biographic metafiction" and the self-reflexivity attributed to literary experimentation in the above claim can quickly evoke the ironic and self-conscious play typical of postmodernist fiction. However, such an easy association can become reductive for two reasons: it limits our understanding of the heuristic value of auto/biographical experiments, and it may obscure our view of the historicity of auto/biographical experimentation by framing it as only a post-WWII phenomenon. One can certainly identify a postmodern scepticism and irony in a branch of life-writing experiments that negates the possibility of auto/ biographical representation-that is, of the writer's ability to reach the core of his or her subject. Such texts constitute what Caitríona Ní Dhúill describes as "anti-biography," embodying a "hermeneutics of suspicion." David Nye's Invented Self: An Anti-Biography from Documents of Thomas A. Edison (1983) is a famous example here: the many Edisons Nye presents to his readers in non-linear fashion do not add up to a coherent, unified self.

But there are also departures from generic conventions that extend, rather than deny, the parameters of auto/biography-be it by choosing a mode of writing that more accurately reflects the condition of the modern subject, a style that is felt to do justice to, and therefore to more faithfully represent, a particular person, or a form that activates additional levels of auto/biographical communication. A well-known example of the latter is Art Spiegelman's auto/biographical comic Maus (1991), a non-realistic graphic representation of Jews as mice and German Nazis as cats. As Irene Kacandes notes, this is a highly effective way to visualise the vulnerability of Holocaust victims vis-à-vis their 
tormentors. Spiegelman thus manages to "convey some aspect of the 'realness' of certain life experiences" 10 by modifying conventional lifewriting forms. In contrast to anti-biography, this second type could be called an "experiment for the purpose of life-writing" (expanding on Kacandes's notion of "experiment for the purpose of autobiography"). ${ }^{11}$ The present essay collection examines both types of experiments: those tending towards anti-biography as well as others that push at the boundaries of existing forms to mould them into something that better suits the writer's efforts of representation.

\section{Victorian ReALism and Auto/Biography's InVisible “Tradition of THE NeW"}

Next to avoiding a too narrow focus on "negative," self-denying forms, the second reason for being cautious about any necessary association of experiments in life-writing with postmodernism is, I believe, more obvious: life-writing, like any other field of literary production, has its own extensive "tradition of the new" 12 that reaches back further than the "postmodernism" label would suggest. Life-writing scholars such as Ruth Hoberman and, more recently, Max Saunders have demonstrated that contemporary experiments in life-writing are clearly prefigured by the work of modernist authors, who challenged the conventions of biography and autobiography no less than (and, in fact, in similar ways as) they did those of other genres. In his influential monograph Self Impression: Life-Writing, Autobiografiction, and the Forms of Modern Literature (2010), Saunders discusses seminal modernist works such as Virginia Woolf's "mock biography" Orlando (1928), Gertrude Stein's Autobiography of Alice B. Toklas (1933), and A.J.A. Symons's metabiographical The Quest for Corvo (1934; fittingly subtitled “an experiment in biography"). For such self-conscious testings of generic boundaries, he introduces the term "auto/biografiction."

Had our concept of life-writing developed in analogy to other literary fields, the prolific experimentation in auto/biography throughout the twentieth century could have registered as a "problem of the new,"13 as a perceived exhaustion of the formal possibilities of life-writing that precludes further innovation. However, this is not the case. Many lifewritings count as "experimental" today and arguably are perceived as such because they continue to be measured against a tenacious, historical standard. Although experimentation has been a staple diet of fiction 
writers and a defining mark of much canonical fiction for centuries, "Strachey and his heirs are still outlaws," Carole Angier maintains, and the "battle for 'experimental' biography has to be fought anew in every generation" as positivist Victorian values prevail to this day. ${ }^{14}$ Angier is certainly not alone in identifying that prevailing standard as the positivist Victorian model of biography. Sharon O'Brien's succinct explanation of the principles of Victorian "realist" biography reveals the frequently evoked "truth-telling programme" 15 of the genre-its obligation to "fact" - as being closely tied to specific modes of representation:

language is a transparent medium capable of representing the world; character and the self are knowable; the cause-and-effect linearity implied by the chronological plot is a reliable way of ordering reality; and the author is a trustworthy narrator who understands the relationship between the private self and the public world. ${ }^{16}$

O'Brien then points to what has become a commonplace in life-writing history: that the development of Victorian biography and autobiography is intricately linked to the development of the nineteenth-century novel and, consequently, that the principles she outlines above apply equally to the realist fiction of the period. Like O'Brien, neo-Victorian scholar Louisa Hadley identifies a persistent investment of contemporary biography in the conventions of Victorian realism that neo-Victorian fiction tends to challenge. She locates the reason for the entwinement of Victorian novel and biography in the concern for the development of character which was preeminent in the period and which lies at the heart of both forms. ${ }^{17}$

Paradoxically, then, it can be argued that our contemporary notion of biography (and, to a lesser extent, autobiography) as a "historical" or "referential" genre is also founded on the narrative strategies espoused by writers of fiction in an earlier era. ${ }^{18}$ "The biographer's art is patterned on Austen, Thackeray, or Eliot, not on Beckett, Faulkner, or DeLillo," O'Brien concludes. "The model here is realism, not modernism or postmodernism, and the assumptions made about biography accord with those made by the readers and writers of realistic fiction."19 In "The Necrophiliac Art?," Martin Stannard speculates on the reason for biography's persistent harking back to Victorian forms, which he believes resides in "the collapse of the realist novel" that has "left a gap" in the literary market: "Readers who prefer a plain tale, authoritatively 
told, turn to biography for the security of well-drawn characters, a hero or heroine, and satisfying closure." 20 Stannard thus evokes biography as an antidote to the literary experimentation of postmodernity, albeit one whose "plain telling," "security of character," and "satisfying closure" render it untrue to life.

On a slightly different note, feminist critics have raised concerns about the dated model of subjectivity these texts project. For Anne-Kathrin Reulecke, Liz Stanley, and Leigh Gilmore, the linear development of a sovereign subject inscribed in this model displays a marked gender bias, which has become naturalised, its "ideological work" rendered invisible by its realist mould. ${ }^{21}$ As will be seen, the role accorded to genre in their criticism-as a "form of symbolic action" that "contribute[s] to the social structuring of meaning," as John Frow defines it ${ }^{22}$-is confirmed by the contributions to this volume.

The concept of genre, Jacques Derrida reminds us, though seemingly promising stable classifications, is founded on a principle of "impurity." 23 This could be taken to mean that the notion of experiment, too-as far as it implies a shifting of generic boundaries and the ensuing "contamination"-is in fact innate to the very idea of genre and thus applies to all genres equally. However, more appears to be at stake in departures from the conventions of life-writing genres. If the truth value of life-writing is seen as dependent on specific formal strategies of representation, as argued by the critics above, experiments with auto/biographical form will almost automatically shed doubt (and light, too) on the ontological status of the represented life, that is, the text's position on the fact/fiction spectrum and, consequently, its truth value.

\section{Genre, Fact, and Fiction}

Narratologists and biography scholars alike have made repeated attempts to theorise the precise relation between fact and fiction in auto/biography. In their entries for the comprehensive 2009 Handbuch Biographie ("Handbook Biography"), Christian Klein and Matías Martínez demonstrate how the tools of narratology can be applied to life-writing texts. They consider aspects such as setting, character, motifs and their combination on the level of story ("Histoire") and aspects such as temporal structure and perspective on the level of narrative discourse ("Discours"). ${ }^{24}$ Insofar as their approach demonstrates that biographical and fictional narratives can be viewed through the same analytical 
grid, their approach resonates with Hayden White's famous postulation of the non-distinction between fact and fiction due to their mutual narrativism. ${ }^{25}$

Others contest such a view, insisting on a categorical distinction between factual and fictional narratives that can be drawn on formal grounds. In The Distinction of Fiction, Dorrit Cohn criticises White for ignoring the "referential level" of historical narrative, which she considers a crucial level of analysis, in addition to those of story and discourse. It is worth recapitulating the central points of Cohn's argument in order to shed light on the generic borders that life-writing experiments face: In biographies and autobiographies, Cohn maintains, the selection of story elements or motifs is necessarily governed by their reference to what she calls the "data base" of "more or less reliable documented evidence of past events." ${ }^{26}$ In answer to White, she makes her point most forcefully when she claims that

A novel can be said to be plotted, but not emplotted: its serial moments do not refer to, and can therefore not be selected from, an ontologically independent and temporally prior data base of disordered, meaningless happenings that it restructures into order and meaning. ${ }^{27}$

Clearly, Cohn's model of fiction at this point would be difficult to apply to biographical fictions such as Janice Galloway's novel Clara (2002), which is overwhelmingly composed of real-world "references" and documented evidence, based on several years of research.

Cohn does concede that problems arise if reference is used as a criterion of distinguishing fact from fiction in absolute terms. That commitment to "verifiable documentation" 28 may be suspended in fictional narratives does not mean that fiction "can not refer to the real world outside the text, but that it need not refer to it." 29 Fictional narratives may contain external, real-world references, but these can be combined with non-factual elements; the selected facts can be imaginatively manipulated in fiction, as fiction is not bound to factual accuracy. In consequence, Cohn says, "external references do not remain truly external when they enter a fictional world," but "are, as it were, contaminated," that is, fictionalised, "from within." 30 As regards the level of selection, then, the question arises precisely what extent or proportion of nonreferential (imaginary) elements would "contaminate" a work of nonfiction and thus render it fiction. Cohn answers this only implicitly by 
claiming that the fact/fiction distinction is "not a matter of degree but of kind," ${ }^{31}$ pointing to distinguishing criteria on the level of discourse.

It is specific processes of narrative configuration on the discourse level, then, which supposedly allow for a more reliable distinction of factual and fictional narratives. Cohn points to certain techniques in the presentation of consciousness, for instance, such as free indirect discourse, which, in contrast to the psycho-narration typical of biography, clearly marks a text as fiction. ${ }^{32}$ By the same token, Ansgar Nünning claims that it is technical procedures on the level of discourse that mark fiction as fiction, citing, for example, dialogue as a "formal privilege of the novel." 33 One can only wonder what Cohn and Nünning would make of Dieter Kühn's biography of Clara Wieck Schumann, from which the following passage is taken:

Clara Schumann, at night, she cannot sleep - her hour of fear. A fit of crying, again, right after she has gone to bed. Fear, again her fear, the deathly fear that her memory might fail her. As she studies a new piece for her impending concert trip to Vienna: a tiny hesitation, a rubato at a high pace, again too high probably, in this rubato: the fear. Fear of not being "able to find" the notes in her head, fear of not knowing how to continue in Vienna, . . . of sitting before a Viennese audience and not know, finished, over, the end! ${ }^{34}$

If a biography makes use of techniques typically found in fiction, this will mark it as "fiction," Cohn and Nünning seem to suggest. Cohn's logic of "contamination" would imply that the "must be based on verifiable fact" stipulation of referential narrative is then immediately transformed into the "can, but need not be" of fiction, thus calling into doubt the historical veracity of the text. Although Clara Wieck Schumann's performance anxiety may well be documented, the immediacy created by Kühn's style in this passage-his use of the present tense, the absence of a main verb in the second and last sentences, the string of staccato phrases, and the exclamation mark at the end-is distinctly "novelistic." The passage appears to reflect the consciousness of a direct observer, who, moreover, has access to the subject's thoughts and feelings. In an essay on "literary biography," which is how the author (whose work has often been called "experimental") classifies his text, Kühn insists that it is entirely based in fact, adding that "of course" a literary biography "has no room for fiction." 35 
As for dialogue as a distinguishing criterion of fiction, it should be noted that dialogue has been specifically identified as a central device for the writer of "creative nonfiction," which, according to Lee Gutkind, includes memoir (a popular life-writing genre) and is founded on "accurate information." 36 Indeed, the short conversation-set out as dialogue-between Marlene Dietrich and her mother in Lara Feigel's recent monograph The Bitter Taste of Victory (2016), ${ }^{37}$ a historical/biographical study of English-language writers in post-war Germany, does not move Feigel's book into the non-referential genre of the novel.

The fact/fiction question has been puzzling (and, alas, vexing) lifewriting theorists for decades. In Borderlines: Autobiography and Fiction in Postmodern Life Writing (2003), an insightful study of a broad range of experimental autobiographical texts, Gunnthorunn Gudmundsdottir even takes "fictional" to "designate the conventions and practices one associates with creative writing - such as structure, poetic or literary descriptions of people and places, ordering of events to create certain effects-rather than simply things that are "made-up." She therefore considers fictionality a "necessary part of the autobiographical process itself and not something external to it, or incompatible with it." 38

It seems that the proliferation of experiments in the vast field of lifewriting has created particular challenges for developing any reliable criteria for an absolute distinction between factual and fictional narrative- a distinction that is, however, felt to have profound implications for the readers and subjects of auto/biographical texts. I make no claims to resolve this conundrum here; rather, my aim is to consider what is at stake in auto/biographical experiments. Recent critical work on biographical fiction can help to illuminate perceived dividing lines between factual and fictional life-writing genres, particularly with regard to the cultural parameters within which experiments in life-writing operate.

\section{The (Non-)Referentiality of Biographical Fiction}

Biographical fiction-or "biofiction"-is a narrative based on the life of a historical person, weaving biographical fact into what must otherwise be considered a novel. It "dispenses with the claim to factual reliability or historical accuracy, permitting a fictional and speculative recreation of the subject's inner life," as Caitríona Ní Dhúill notes, ${ }^{39}$ and the protagonist usually bears the subject's name. ${ }^{40}$ While biofiction is often considered a product of postmodernism, ${ }^{41}$ there are, in fact, copious texts from 
the early twentieth century which would correspond to this definition. ${ }^{42}$ Nor would it be true to say that biographical fiction is a priori "experimental": Susan Vreeland's The Passion of Artemisia (2002), for example, though certainly interesting in terms of its gender politics and its perspective on art history, is written in a very conventional, realist mode. ${ }^{43}$

More recently, Michael Lackey has published several foundational studies on the nature and history of biographical fiction of the late twentieth and twenty-first centuries, including The American Biographical Novel (2016), in which he attempts to delineate the biographical novel from other forms of narrative. For Lackey, biofiction can be distinguished from "biography" by its "creative invention"; biographical novelists, he argues, "invent stories that never occurred in order to answer perplexing questions, fill in cultural lacunae, signify human interiors, or picture cultural ideologies." $44 \mathrm{He}$ thus seems to situate the distinguishing mark of fiction exclusively upon the level of story, evoking Cohn's notion of non-referentiality, the idea that the novelist also draws on elements other than documented facts. However, the conclusions he draws about the distinction between biofiction and biography go beyond Cohn's narratological account: for Lackey, apparently, biofiction is not biography, because it fulfils a different purpose.

His view contradicts Ina Schabert's early study on what she terms "fictional biography." Schabert defines this as narrative "engaged in the comprehension of real historical individuals by means of the sophisticated instruments of knowing and articulating knowledge that contemporary fiction offers." 45 Fictional biographies serve to "contribute to the understanding of an individual, even to the subjective essence of his or her personality," Schabert declares, as "a medium of interpersonal knowing." 46 Laying aside the fact that to postmodern readers the idea of capturing the "essence" of a historical person may sound overly optimistic, her definition suggests that biographical fiction's prime goal is to represent the historical subject, albeit with different means than the "straight" biography. Not so for Lackey, whose definition reveals that he regards biofiction as a non-referential genre because the novelist, unlike the biographer, uses an actual historical life as a springboard for something other than making the person "known." Lackey therefore claims biographical fiction to be categorically different from "life-writing," which he uses interchangeably with "biography," reading both terms as denoting factually accurate attempts at an objective representation of a life. 
The matter is further complicated by Kacandes's argument in "Experimental Life Writing" (2015). Here she reflects on the forms of experiments that readers will usually tolerate without feeling that a breach of contract is taking place. According to Kacandes, readers have "a high tolerance for experimentation that might be construed as revealing or representing the complexity of reality." These include "techniques to render the layers of the human psyche, split subjectivity, or the human experience of time and space" —none of which "disqualify ... the text as life writing." 47 One cannot help but notice that the experiments in auto/ biography Kacandes identifies ("to render the layers the human psyche" and "human experience of time and space") are conspicuously reminiscent of what Lackey sees as the hallmark and purpose of biographical novels (to "signify human interiors") that distinguish biofiction from biography.

The difficulties of drawing a distinction between biofiction and biography in terms of their cultural objective come further to the fore when we take into account John Keener's decision in Biography and the Postmodern Historical Novel (2001) to consider biography and biographical fiction "collectively as a continuum rather than a dichotomy." Keener uses the umbrella term "biographical narrative" and insists that "any such narrative can be viewed as a biographical text since, in one way or another, it contributes to the cumulative cultural life story of that individual." ${ }^{48}$ His view anticipates some of the recent work that considers life-writing from the critical perspective of cultural memory studies. Fictional and factual varieties of "afterlives," such scholarship argues, feed into the same notional archive of collective remembrance on which societies draw when imagining their past and, through it, establish their cultural identity. ${ }^{49}$ Biography, autobiography, and biographical fiction can in this sense be seen to perform the same cultural work.

Lackey's demand that biographical novels not be read in the way biographies are-that is, as attempts at a faithful representation-is not only sidestepped by cultural memory studies; it is also repeatedly being challenged by public responses to biofictional texts. This is most forcefully demonstrated by the scandals occasionally triggered by biographical fictions, as when the London headquarters of Gibson Square Books were firebombed in 2008 at the publication of Sherry Jones's The Jewel of Medina. ${ }^{50}$ Jones's novel, about one of the wives of prophet Muhammad, had earlier caused controversy when Ballantine Books, who were originally to publish it, cancelled the book after a professor for Middle 
Eastern Studies raised objections about its "deliberate misinterpretation of history." 51 Two years earlier, former football manager Johnny Giles took UK publisher Faber \& Faber to court when he felt that he had been libelled in David Peace's The Damned Utd, an acclaimed biographical novel about football manager Brian Clough. Giles won the case and, consequently, Faber \& Faber took out some of the references to Giles in the novel. ${ }^{52}$

Thus, no matter whether biographical novels should be read as fiction (and, thus, as non-referential), their biographical content clearly interests readers and is recognised as contributing to the subject's afterlife. In that sense, it always strikes one as a little bizarre if the front matter of a biographical novel features a standard disclaimer such as this one, taken from Vreeland's The Passion of Artemisia: "All characters in this publication are fictitious and any resemblance to real persons, living or dead, is purely coincidental." 53 Sometimes such disclaimers are uttered by authors directly. Joyce Carol Oates responded to critics who berated her Marilyn Monroe novel Blonde (2000) for the liberties taken with biographical facts, that her work was to be read purely as fiction rather than as biography. Sarah Churchwell, whose metabiography The Many Lives of Marilyn Monroe (2004) groups Oates's novel with other works that perpetuate popular stereotypes about Monroe, aptly brings the unease such a demand evokes to the point when she concludes, "it is not crudely literal to acknowledge that Marilyn Monroe is not totally a product of Joyce Carol Oates's imagination, and that the story Oates tells is also not entirely a product of her imagination." 54 Controversies like these demonstrate what is at stake in fictional representations of real people, and why the distinction between fact and fiction is sometimes considered to be of great import. The reproach laid at the door of the fictionalisers will not normally carry any legal implications, but it certainly raises fundamental questions about the ethics of such representations. ${ }^{55}$

\section{Unsettling Labels and Pacts: Experiments in Life- WRITING}

What narratologist Dorrit Cohn's and biofiction scholar Michael Lackey's respective conceptions of the absolute difference between factual and fictional modes share is an implicit assumption that a text will issue clear signals that permit readers to assign it to either one or the other mode. In life-writing theory, such signals are seen to activate a 
"pact" between author and reader which determines the reception of a text. Most famously, Philippe Lejeune coined the notion of an "autobiographical pact" that spells out the unity of author, narrator, and autobiographical subject. According to Lejeune, readers of autobiography are thus offered an implicit guarantee that the author, whose name is on the book cover, is also the narrative voice in the text and is truthfully telling his or her own life-story. ${ }^{56}$ In analogy to Lejeune, a similar pact has been proposed for biography, amounting to a promise that the claims made by the biographer-who is someone other than the subject of the workare accurate and true, in the sense of verifiable by biographical records. ${ }^{57}$

This idea of a "pact" between author and reader resonates with Cohn's claim that the distinction between referential and fictional texts is absolute and that we are consequently led to read a given text "in one key or the other." 58 The above discussion of Cohn's argument has demonstrated, however, that in some cases it is, in fact, rather difficult to determine the precise element that will supposedly "key" the reader reliably into a particular mode. In Lackey's work on biofiction, the question of recognising a text as one or the other does not even arise because the biographical novels he studies are labelled as novels. They sometimes bear "novel" in their subtitle, are marketed as novels, and usually include the traditional disclaimer ("This is a work of fiction...") in their front matter, hence Lackey's insistence that they should be read as fiction, not measured against historical facts.

Yet many experiments in life-writing playfully undermine such secure labelling or dispense with "keys" to their reception altogether. A striking example of an apparently "unclassifiable" experimental narrative is Rosemary Kay's Between Two Eternities (2000), an imaginative account of the life of a prematurely born baby in intensive care, written in the first person from the baby's point of view. The book was published by Headline (UK) as a memoir in 2000. In the same year, it was published by St Martin's Press (USA) and Random House (Canada) under the title Saul-as a novel. Janice Galloway's novel Clara (2002), which, as mentioned above, is based on several years of research into the life of Clara Wieck Schumann, was marketed and reviewed as a novel. The interview with Galloway in this volume reveals that, as far as she is concerned, she has written a "book" about the pianist; the genre label "novel" was chosen by her publisher. Similarly, the three novels of Jordi Soler's trilogy La guerra perdida (2004-2009), discussed in this collection by Gunnthorunn Gudmundsdottir, are consistently labelled as novels, but 
their auto/biographical nature is stressed in reviews and interviews with the author. Eveline Kilian's article on Christine Brooke-Rose's experimental autobiography Remake (1996) in this volume details the many peculiarities of Brooke-Rose's text and goes some way towards explaining why it was published without a genre designation. These are just some examples of experimental life-writings that defy, subvert, or shed doubt on established genre categories. They also point to the fact that it is not necessarily the author who provides the "key" for reading an experimental text as factual or fictional (and, thus, who consciously writes in that particular key) but that the label chosen may depend on publishers' profiles and marketing agendas.

What kinds of experiments in life-writing can we identify, then, that make publishers withhold genre designations altogether or that let readers doubt the validity of the pact they normally expect to enter on encountering auto/biography? In the following, I will provide a quick survey of the textual levels on which experiments have been conducted in modern auto/biographical narratives.

\section{The Subject of Auto/Biography}

Virginia Woolf's Flush: A Biography (1933) is a classic example of a life-writing text with an unusual subject that has scholars debate to this day whether it ought to be read as, indeed, a biography, as a biographical novel (or novella), or as a historical novel. It can be argued that Woolf's canine biography of Elizabeth Barrett Browning's cocker spaniel effectively expanded biography to include non-human lives, just as more recently biographers have taken to writing the lives of subjects not delimited by a biological notion of birth and death, such as cities and books (e.g. Peter Ackroyd's London: The Biography, of 2000, or Alberto Manguel's Homer's Iliad and Odyssey: A Biography, of 2008). ${ }^{59}$ Experiments with the "subject" of life-writing can further involve a blending of biography and autobiography, as in A.J.A. Symons's classic metabiography The Quest for Corvo, which dramatises the biographical process and thus recounts a passage in the writer's own life. But they can also include what Kacandes terms "the work's focus," citing Roland Barthes par Roland Barthes (1975) as an example-a "literary self-portrait" in which Barthes "put[s] his intellect on display" 60 rather than recounting biographical facts. 
Rendering the conventions of auto/biographical narratives visible in the most obvious manner, the choice of an unusual historical subject (or "focus") automatically opens up a metabiographical layer of interpretation. This is also true for most other types of experiments discussed here: marked departures from the standards of auto/biography bring the basic premises of auto/biography into view as much as they present alternative ways of writing a life.

\section{Generic Composites}

Some writers ostentatiously integrate elements into their texts that would normally be associated with other genres, like Ford Madox Ford does when expounding on his and Conrad's theory of writing in extensive passages of Joseph Conrad: A Personal Remembrance (1924). Peter Handke's Storm Still (2010) mixes elements from classical tragedy, Shakespearean tragedy, and auto/biography; Jordi Soler resorts to well-known tropes of magic realism and folk tales in La fiesta del oso (2009)—a choice that, as in Handke's text, expresses the author's attempt to make sense of the entanglements of personal and national history. ${ }^{61}$

A type of experiment often entailed in such mixing of seemingly incongruous generic elements is the inclusion of invented characters or events. Thus, Soler's recourse to magic realism in La fiesta del oso is manifest in an enigmatic, witch-like character as well as a giant. Fay Weldon's Rebecca West (1985), catalogued as fiction, is composed of the author's fictional letters to West, illuminating a particularly difficult period in West's life about which little documentation exists; Amia Lieblich's Conversations with Dvora: An Experimental Biography of the First Modern Hebrew Woman Writer (1997) is similarly cast as the author's imaginary dialogue with her historical subject; J.M. Coetzee takes this strategy a step further in his "anti-autobiographical"62 Summertime (2009) through conversations conducted between a fictional biographer and acquaintances of his subject John Coetzee, a device that arguably "contaminates"- to use Cohn's diction-whatever biographical material the author has chosen to reveal. In Peter Ackroyd's Dickens (1990), some chapters have Charles Dickens converse with characters from his own novels or with other authors. More than speculate on the subject's attitudes and motivations, such imaginative passages in life-writings about writers arguably "reflect ... the fictionalizing powers of their 
subjects," 63 as Saunders points out. Paradoxically, they can thus be seen as contributing to the effort of "catching a likeness" that for Hermione Lee lies at the heart of the biographical endeavour. ${ }^{64}$

\section{Style}

There are experiments in life-writing that disrupt reader expectations by adopting stylistic devices of experimental fiction. B.S. Johnson's Trawl (1966), for instance, is frequently marked by a distinctly Beckettian syntax and tone that counteract the text's autobiographical narrative, as Andy Wimbush demonstrates in his analysis of Trawl in this collection; Christine Brooke-Rose's depersonalised use of the present tense for reflecting the impressions of a central consciousness in Remake (1996) are also deployed in the author's overtly fictional experimental texts and thus make it difficult to see her autobiographical texts as separate from her fiction. ${ }^{65}$

\section{Structure}

The linearity traditionally expected of auto/biography is frequently subverted in experimental narratives. This may affect the text's temporal structure-as in Jackie Kay's memoir Red Dust Road (2010), ${ }^{66}$ whose present-day chapters are interspersed with chapters about her parents' past, thus pointing to the pervasiveness of the past in the present. Such fragmentation can also register as a structural echo of the documents (un)available to the biographer, thus pointing to the gaps in any life narrative, which drives home to the reader his or her own role in the narrativisation of biographical material. Will Slocombe's "Dining with Dr Wilson," a fragmented text about psychiatrist Isabel Grace Hood Wilson's engagement with famous patients through a collection of table mats, serves as an example here, which the author discusses in this volume. Another example is László F. Földényi’s biography Heinrich von Kleist: Im Netz der Wörter (1999; "Heinrich von Kleist: In the Web of Words"), which consists of ninety-six thematic chapters in alphabetical order of their titles - an arrangement that systematically breaks with the "phantasmagoria of the linear life course," as Klein notes. ${ }^{67}$

The device of the portmanteau narrative, by contrast, does not so much upset the chronology of a story as its coherence and internal logic. Javier Marías's Negra espalda del tiempo (1998; Dark Back of Time) 
illustrates this: the unifying story arc generally expected of auto/biographical texts is here replaced with the apparent randomness of loosely connected episodes, which provide, however, a more genuine reflection of life, as María Alhambra Díaz argues in her contribution to this volume.

Sometimes authors will opt for a collection of poetry as a vehicle for life-writing, which impacts on the structure of the authors' auto/ biographical projects in so far as it liberates them automatically from the constraints of coherent narrative. It is easy to see how poetry can be appropriated as a medium for autobiography: writing about oneself requires activating one's memory, and individual memories of our past do not usually come to us in a coherent, linear form. Rather, they surface through the floating, disconnected thoughts and impressions that poetry is so apt to convey, as Jackie Kay's Fiere (2011) demonstrates. Will Slocombe's chapter reveals that poetry can equally serve as a valid medium for biography: he discusses his poem "Another's Pleasure" as an example of montage, in which the experiences and impressions of a nineteenth-century criminal are juxtaposed to the pseudo-medical discourses surrounding his incarceration. The brevity of the individual poem easily allows for such experiments with structure and layout-experiments that have a long tradition in modern poetry.

What montage often entails, as in Slocombe's example, is a perspectival structure that breaks with the single point of view of traditional auto/ biography by admitting different voices into the writer's account. This is a trait that also marks Kay's The Adoption Papers (1991), which narrates the story of the author's adoption in a contrapuntal arrangement of the birth mother's, the adoptive mother's, and the adoptee's voices. In Red Dust Road, Kay similarly leaves room for other characters to recount their shared past, as Pietra Palazzolo points out in this volume. Susanna Egan discusses such multiplicity of voice in autobiography under the label of "dialogic" autobiography, stressing the relational nature of subjectivity it projects. ${ }^{68}$ An interesting case of such dialogism in autobiography is also examined by Antonio Lunardi, who unravels the complex layering of perspectives in Lalla Romano's Romanzo di figure (1986), an intermedial text that brings the author's view of her past into dialogue with the perspective of her readers as well as with the perspective, literally, of those who authored the photographs on which she comments.

The frame narrative, finally, constitutes a crucial structural deviation from the conventions of auto/biography that Ursula Hurley exploits in 
her current project of writing the life of Elizabeth Cary. Hurley's chapter outlines how she has turned her own biographical quest into the frame through which she presents the life of Cary, who is in turn positioned as biographer of the biblical Mariam - a strategy that makes the constructedness of life-writing visible on several levels.

\section{Intertextuality and Metalepsis}

The idea of a biographical or autobiographical pact between author and reader is meaningful only if we can presuppose a text's tenable relation to "the real" and the possibility to delineate that text from others that rely on invention. Many experimental writers subvert this distinction by establishing cross-textual links between their life-writings and works that are clearly marked as fiction. Eveline Kilian's chapter in this volume points out the intertextual links between Christine Brooke-Rose's autobiographical Remake and her earlier novel The Dear Deceit (1960), for example. Brooke-Rose forges these by direct references to her novel in Remake and by the use of some of the same names, resulting in a permeability between her fiction and autobiography that calls into doubt the ontological status of characters in both works. Jackie Kay titled a chapter of her memoir Red Dust Road "Fantasy Africa"-a title that she had previously used for a chapter in her novel Trumpet (1998), which, in turn, was inspired by the biography of pianist Billy Tipton. La fiesta del oso, the third part of Jordi Soler's trilogy of novels La guerra perdida, recounts the author's presentation of his earlier novels. It even includes a poster announcing his book presentation, complete with Soler's photograph. Again, this metaleptic intrusion of the real world into the novel can be said to considerably destabilise the boundaries between fact and fiction.

\section{Play with Names and Pronouns}

In many instances, the metaleptic shifts in experimental auto/biography are induced by the author's play with names and pronouns, as the above examples demonstrate. However, such play need not necessarily involve metalepsis. It can also take the shape of an apparent misalignment of names or pronouns and their referents. This is exemplified by Ford Madox Ford's use of the designation "the writer" in Joseph Conrad: A Personal Remembrance to evoke a sort of composite Conrad-Ford persona as well as his use of the first-person plural "we" in connection with 
experiences and statements pertaining to Conrad only. ${ }^{69}$ Another classic example is Gertrude Stein's final revelation in The Autobiography of Alice B. Toklas (1933) — of herself as the author and originator of the "narrating I"70_-which startles unsuspecting readers to this day.

For Cohn, significantly, it is precisely the nominal difference between author and narrator in a first-person life narrative that indicates that the work is a fiction. The example she cites is, however, Charlotte Brontë's Jane Eyre, a "fictional autobiography" whose subject Jane, though autobiographically inspired, is indeed an invention. ${ }^{71}$ In Autobiographies of Others, Lucia Boldrini points out that the link between pronouns and their referents is somewhat more complicated in what she terms "heterobiographies,"72 that is, biographical fictions about historical figures written in the first person, such as Manuel Vázquez Montalbán's selfsearching Autobiografía del general Franco (1992). Boldrini highlights how an obvious breach of the autobiographical pact - the autobiography is here written by someone other than the subject-raises central questions about "the ethics of the voice and the ethical implications of literary practices of representation." 73

However, the works Boldrini discusses are still clearly labelled as "novels," which is not the case in Andrew Motion's Wainwright the Poisoner (2000), an "experimental biography" that could nevertheless be considered a heterobiography in Boldrini's sense. Motion takes on the firstperson pronoun "I," presenting his book as a memoir written by artist and serial killer Thomas Griffiths Wainwright, whose efforts at denial and self-justification are counteracted by the evidence Motion provides in numerous footnotes. Critics seem to have generally deemed Motion's book an "honourable failure," 74 which-in view of the central importance of labels in life-writing-makes one wonder whether it would have been a greater success had the author chosen to present it as fiction.

Christine Brooke-Rose, by contrast, does relate her own experiences in Remake but renounces the use of the usual personal and possessive pronouns in favour of "the little girl," "Tess," and "The old lady," as she calls past versions of herself. Joseph Fichtelberg proposes the term "dismemberment" (in analogy to "re-membering") for "the autobiographer's radical separation from the dead selves borne down by time" 75 - a strategy that undermines the notion of coherence and organic wholeness that autobiography is traditionally expected to confer upon lived experience and personal identity. 
In a different vein, the protagonist and narrator in the first part of Soler's trilogy, Los rojos de ultramar (2004), is called Soler but is a professor of anthropology rather than an author, turning the text into what has come to be called "autofiction." "76 More radically, Peter Handke's Storm Still realigns names of members of his own family with the documented experiences of Carinthian Slovene resistance fighters during World War II, as Vanessa Hannesschläger's chapter reveals.

Although such play with pronouns and names can be frequently found in experimental auto/biography, often resulting in the subversion, or downright shattering, of the auto/biographical pact, authors in the present volume demonstrate that its specific function varies considerably in individual works.

\section{Media}

As Kacandes notes, the last decades have seen an explosion in experiments with the media of life-writing, many of which have gone beyond print, extending to performance, audio-visual media such as film, and digital media (in the form of blogs, for instance), for which Kacandes proposes the broader term "life narrative," following Smith and Watson. ${ }^{77}$ Like the present volume, her review chapter focuses on life-writings in the narrower sense of print. Kacandes cites such seminal examples of graphic auto/biography as Spiegelman's Maus (1991) and Marjane Satrapi's Persepolis (2000), and Michael Ondaatje's novelistic memoir Running in the Family (1982), which contains family photographs but features complicated and partly obscure text-image relations that create their very own problems of reference. Lalla Romano's Romanzo di figure is another example of a multi-modal life narrative, constructed around a series of photographs, as is Galloway's biographical novel Clara, which includes examples of musical notation. While images are, of course, a staple ingredient of biographies, normally used to illustrate, and arguably, to verify, the biographer's narrative through co-reference, they can be shown to take on varying functions in experimental life-writings.

I would argue, however, that experiments with the medium or material form of life-writing can also take place within the confines of the written word. On the one hand, they may consist in conspicuous layout and typographical choices, as for example in Will Slocombe's montage poem "Another's Pleasure" or Galloway's use of differently sized letters to indicate volume and emotional intensity in Clara. On the other hand, 
there are covert intermedial experiments that affect the verbal text indirectly. ${ }^{78}$ Alhambra Díaz's chapter on Marías's Dark Back of Time sheds light on the ways in which an initial reference to a film that the protagonist sees induces a reading of Dark Back of Time that conceives the novel's loose, metaleptic structure as an echo of that of the film.

\section{The Chapters in This Book}

The contributions to this collection examine experiments in life-writing whose departure from conventional generic modes is shown to have heuristic value. Long ago, Virginia Woolf postulated biography's dependence on techniques associated with fiction to fulfil its purpose of bringing a character to life, ${ }^{79}$ and it is certainly no coincidence that most authors studied here are experimental writers in other genres too and often already were before they turned to life-writing. However, the contributions in this volume reach beyond the pan-fictional view of life-writing implied in Woolf's statement. Drawing on the tools and techniques of other genres does not automatically render a life-writing text experimental, after all. Rather, the texts studied here can be considered innovative in auto/biographical as well as in general literary terms.

Overall, this volume covers several national literatures (British, Spanish, Italian, Austrian) and a broad spectrum of life-writing genres. Studies of both biographical and autobiographical texts have been included, as well as of a range of in-between forms that highlight the continuum existing between the two modes. ${ }^{80}$ Whereas most of the texts examined by our contributors stem from the late twentieth and the twenty-first centuries, Saunders's chapter on Ford Madox Ford helps to place recent experiments in a longer diachronic perspective.

Thus, in the first part, "(Dis)Solving the Self: Methods and Modes," Max Saunders, Andy Wimbush, and Eveline Kilian investigate narratives inspired by personal memories, which are complicated by their authors' unusual impressionist, self-reflexive, and intertextual methods. Saunders argues for Ford's pioneering role in modernist experiments with lifewriting and (meta)fiction. His reading of Ford's Joseph Conrad: A Personal Remembrance (1924) posits Ford's controversial memoir/novel not only as a specimen of the literary impressionism espoused by both Conrad and Ford but also as an example of a form of "postmodernism within modernism," due to its self-reflexive stance, its exploration of reference and subjectivity in auto/biography. 
Andy Wimbush examines B. S. Johnson's debt to Samuel Beckett through a reading of Johnson's autobiographical non-fiction novel Trawl (1966), which frequently adopts the syntax, tone, and humour particularly of Beckett's "trilogy" Molloy, Malone Dies, and The Unnamable. However, although these stylistic echoes draw Trawl close to Beckett's experimental fiction, Wimbush demonstrates that Beckett's trademark cynicism and despair are ultimately found unsuitable for narrating Johnson's personal experiences.

Eveline Kilian studies Christine Brooke-Rose's two autobiographiesof-sorts, Remake (1996) and Life, End of (2006), as striking examples of Brooke-Rose's experimental method that the author also applies in her fiction. The two texts are written in present tense, avoid personal and possessive pronouns, refer to past selves by different names, include theoretical reflections on life-writing, memory, and selfhood, and reuse material from her novels, constantly undermining their own generic status. Kilian argues that rather than extend the form of autobiography, Brooke-Rose's formal experiments are geared towards exposing and questioning staple generic distinctions altogether.

In Part II, "Genre B(l)ending: Self, Family, and the Nation," autobiography opens out to collective history. The experimental life-writing projects discussed by Pietra Palazzolo, Gunnthorunn Gudmundsdottir, and Vanessa Hannesschläger are marked by fragmentation and recourse to myth, folklore, drama, or poetry. A further common concern of these contributions is experimental auto/biography's implication in cultural identity, national history and politics. Palazzolo's chapter examines Jackie Kay's search for a suitable autobiographical form across different genres in relation to the trope of the journey. Focusing on Kay's memoir Red Dust Road (2010) and her poetry collection Fiere (2011), Palazzolo confirms Bart Moore-Gilbert's contention that postcolonial life-writing accords central importance to "geo-political location" and is often marked by a conception of subjectivity as dispersed and decentred as well as by an emphasis on dialogical, relational selfhood. ${ }^{81}$ Palazzolo argues that Kay's retelling of the story of her transcultural adoption and her experimental use of autobiographical and fictional/poetic narrative modes provide a fresh perspective on the concept of a layered self pervading her works.

Gunnthorunn Gudmundsdottir examines the genres at play in Jordi Soler's trilogy La guerra perdida (2004-2009), in which the author traces his family's past, linking it to historical accounts of the 
Spanish Civil War and the as-yet-unresolved fractures of the civil war within Spanish post-Franquist identity. Gudmundsdottir sheds light on Soler's use of source material, on the author's autobiographical investment in family history and national history, and on the narrative modes employed, settling on Gratton's and Saunders's term “autobiographic metafiction" to capture this complex experiment in life-writing.

The final chapter in this section, by Vanessa Hannesschläger, is devoted to Austrian author Peter Handke's stage text Immer noch Sturm (2010)/Storm Still (2014). Life-writing scholars have long pointed to the relation of auto/biography and dramatic technique, ${ }^{82}$ and Hannesschläger analyses Handke's multi-layered reconfiguration of the dramatic genre for the purposes of life-writing, identifying elements of classical and Shakespearean drama. She outlines the historical context of Storm Still, that is, the Carinthian Slovene resistance against the National Socialist occupation during the Second World War, and illuminates Handke's unusual handling of historical sources: his fictionalising of the biographies of his family members by ascribing to them the documented experiences of resistance fighters.

The two chapters making up Part III, "Intermedial Experiments in Life-Writing," consider auto/biographical experiments which, visibly or covertly, draw on other media in the telling of lives: photography and film. Antonio Lunardi traces the development of Lalla Romano's Romanzo di figure through its various editions $(1975,1986,1997)$. The work consists of a series of photographs - of herself, of her parents, of places she grew up in, mostly taken by her father-to which the author has added comments. Drawing on Erich Auerbach's understanding of the classical and medieval concept of figura as a dynamic form of representation and signification that links different moments in time, Lunardi outlines how Romano's comments, as interpretive acts, can affirm or deemphasise the photographs' auto/biographical reference and how Romanzo di figure's increasingly loose word-image relations require the reader to actively complete the narrative.

María Alhambra Díaz uses a filmic reference in Javier Marías's autobiographical novel Dark Back of Time (Negra espalda del tiempo, 1998) as a lens through which to observe the author's half-ludic, half-uncanny approach to the intersections between biography, autobiography, and fiction, between life and death. Her chapter moves between three alternative readings of the relation between Dark Back of Time and Disney animation extravaganza The Three Caballeros (1944)—what she, taking 
up the title of the conference in which this collection finds its origin, "Biography and/as experimental fiction," terms "and," "a," and "and/ as"-in order to explore the novel's experiment with the relations between fiction and life-writing.

In Part IV, "Experimenting with Lives: Writers Reflect on Their Craft," practicing biographers Will Slocombe and Ursula Hurley give an insight into their recent experimental works or works-in-progress, shedding light on the biographer's responsibility towards his or her subject and, in particular, on their search for a suitable form. They reflect on conceptual shortcomings of certain narrative modes, on the failure to find a publisher, and on the often uneasy compromises that commercial publishing demands of experimental writers. Using the intertwined concepts of exegesis and eisegesis, Slocombe's chapter gives an insight into two cross-generic life-writing projects concerned with the history of psychiatry, through the figures of psychiatric patient William Ross Tuchet and influential psychiatrist Isabel Wilson. The author outlines the visible links his works establish between psychological projection and interpretative acts and reflects on the ways in which his biographical subjects are thus revealed to be "partial" representations of the actual historical personage.

Hurley explains how her turn towards an experimental form and fictional strategies led her to a more "truthful" way of representing the extraordinary life of Elizabeth Cary, a pioneering Early Modern author, social activist, and religious dissenter. The multiple frames of her narrative evolved in order to accommodate the increasingly urgent questions of genre, gender, and historical narrative raised by the social position of women in previous eras and the dearth of historical records about them. These are concerns that also come to the fore in the extended interview with Janice Galloway about her award-winning biographical novel Clara (2002), which rounds off the final section of this collection. Beyond presenting the story of one "exceptional" woman, Galloway's narrative, like Hurley's, pays attention "to the condition of women in history," highlighting the sex/gender system her subject had to negotiate, which for Rachel Gutiérrez constitutes a defining trait of feminist biography. ${ }^{83}$ Galloway sheds light on her formal experiments with typography and layout, explains how her nationality impacts on her writing practice, and reflects on her distrust of genre labels and the idea of "truth" in life-writing.

The array of genres and modes of writing, concerns, texts, writers, nationalities, and cultural backgrounds considered in this collection is at 
once extremely rich and varied, emphasising difference and range over homogeneity, and inevitably partial, covering by necessity only a small fraction of that potentially infinite array. What Lucia Boldrini and I hope this volume does, however, is to offer a valuable contribution to the ongoing debate on the ever-evolving experimenting with, reflecting on, and intertwining of "auto," "bio," "fiction," and "graphy."

\section{Notes}

Supported by the Austrian Science Fund (FWF): T589-G23.

1. Zachary Leader, "Introduction," in On Life-Writing, ed. Zachary Leader (Oxford: Oxford University Press, 2015) 1.

2. Sidonie Smith and Julia Watson, Reading Autobiography: A Guide for Interpreting Life Narratives (Minneapolis: University of Minnesota Press, 2010), 3-4.

3. Hermione Lee, Biography: A Very Short Introduction (Oxford: Oxford University Press, 2009), 5.

4. At a recent symposium entitled "After-Image: Life-Writing and Celebrity" (19 Sept. 2015) at the Oxford Centre for Life-Writing, for instance, novelist Andrew O'Hagan was featured as one of the plenary speakers. On 22 June 2016, I organised a Roundtable on "The Ethics of Biographical Fiction" at the King's College London Centre for Life-Writing Research.

5. Alison Flood, "AS Byatt Wins $€ 150,000$ Erasmus Prize for 'Exceptional Contribution to Culture'," Guardian, 18 January 2016, https://www.theguardian.com/books/2016/jan/18/as-byatt-winserasmus-prize-award-contribution-culture.

6. Andrew M. Colman, "Experiment," in A Dictionary of Psychology (Oxford: Oxford University Press, 2009), http://www.oxfordreference.com/view/10.1093/acref/9780199534067.001.0001/ acref-9780199534067-e-2946.

7. It must be noted that in some ("natural") experiments in the sciences, "what may have started as an attempt to test ends as a voyage of discovery, as the results suggest new lines of inquiry." (Michael Ruse, "Experiment," in The Oxford Companion to Philosophy (Oxford: Oxford University Press, 2005), http://www.oxfordreference.com/view/10.1093/acref/ 9780199264797.001.0001/acref-9780199264797-e-836). In this respect, literary experimentation emerges as not entirely dissimilar to its scientific counterpart, after all.

8. Joe Bray, Alison Gibbons, Brian McHale, "Introduction," in The Routledge Companion to Experimental Literature, ed. Joe Bray, Alison Gibbons, and Brian McHale (London: Routledge, 2012), 1. More 
specifically, work that displays an explicit concern with its own premises as life-writing has recently been theorised as "metabiography." See, for example, Edward Saunders, "Defining Metabiography in Historical Perspective: Between Biomyths and Documentary," Biography 38, no. 3 (2015): 325-342.

9. Caitríona Ní Dhúill, "Towards an Antibiographical Archive: Mediations Between Life Writing and Metabiography," Life-Writing 9, no. 3 (2012): 286.

10. Irene Kacandes, "Experimental Life-Writing," in The Routledge Companion to Experimental Literature, ed. Joe Bray, Alison Gibbons, and Brian McHale (London: Routledge, 2012), 382-383.

11. Following Max Saunders, Kacandes juxtaposes this to "experiments for the purpose of fiction," by which she means "techniques, manipulations, additions, or falsifications that only seem to heighten the drama of the story and/or to aggrandize the individual" (Kacandes, "Experimental Life-Writing," 382).

12. Bray, Gibbons, and McHale, "Introduction," 4.

13. Ian Buchanan, "Avant-Garde," in A Dictionary of Critical Theory (Oxford: Oxford University Press, 2010), http://www.oxfordreference.com/view/10.1093/acref/9780199532919.001.0001/ acref-9780199532919-e-59.

14. Sally Cline and Carole Angier. The Arvon Book of Life-Writing: Writing Biography, Autobiography and Memoir (London: Methuen Drama, 2010), 58.

15. Jürgen Schlaeger, "Biography: Cult as Culture," in The Art of Literary Biography, ed. John Batchelor (Oxford: Clarendon Press, 1995), 67.

16. Sharon O'Brien, "Feminist Theory and Literary Biography," in Contesting the Subject: Essays in the Postmodern Theory and Practice of Biography and Biographical Criticism, ed. William H. Epstein (West Lafayette: Purdue University Press, 1991), 125. It should be noted that autobiography, which bears a distinct relation to processes of memory and introspection and which has been recognised, and theorised, as a literary form much longer than biography, has not been subject to quite the same strictures. However, it can be argued that many autobiographies of the twentieth and twenty-first centuries, too, depict "a process of personal transformation founded on the belief in personal progress" in a linear narrative that "works toward the achieved 'I" (Samantha Matthews, "Autobiography," Oxford Bibliographies, 24 July 2013, http://www.oxfordbibliographies. com/view/document/obo-9780199799558/obo-97801997995580023.xml) and imply a claim to self-knowledge, in the spirit of Victorian autobiography. 
17. Louisa Hadley, Neo-Victorian Fiction and Historical Narrative (Basingstoke: Palgrave Macmillan, 2010), 33. Like other scholars before her, Hadley points to the central role of the Bildungsroman in Victorian literature. A canonical work like Jane Eyre can be conceived as a fictional autobiography (Hadley, Neo-Victorian Fiction, 34).

18. In more general terms, the tension between the "art" of storytelling, the art of evoking personality, on the one hand, and the expectations we bring towards biography as an act of faithful "historiography," on the other, has of course been amply debated by biography theorists-notably in Woolf's famous coupling of granite and rainbow in "The New Biography" (Collected Essays, Vol. IV, London: The Hogarth Press, 1967), 229.

19. O'Brien, "Feminist Theory and Literary Biography," 125.

20. Martin Stannard, "The Necrophiliac Art?," in The Literary Biography: Problems and Solutions, ed. Dale Salwak (Basingstoke: Macmillan, 1996), 33.

21. Leigh Gilmore, "The Mark of Autobiography: Postmodernism, Autobiography, and Genre," in Autobiography and Postmodernism, ed. Kathleen Ashley and Leigh Gilmore (Amherst: The University of Massachusetts Press, 1994), 9-10; see also Liz Stanley, The Auto/ Biographical I: The Theory and Practice of Feminist Auto/Biography (Manchester: Manchester University Press, 1992), 249; and AnneKathrin Reulecke, “'Die Nase der Lady Hester”: Überlegungen zum Verhältnis von Biographie und Geschlechterdifferenz," in Biographie als Geschichte, ed. Hedwig Röckelein (Tübingen: Edition Diskord, 1993), 123-125. Reulecke explicitly proposes (post)modern narrative strategies as a more appropriate way of conveying subjectivity (Reulecke, "Die Nase der Lady Hester," 136-137).

22. John Frow, Genre, The New Critical Idiom (London: Routledge, 2006), $1-2$.

23. Jacques Derrida, "The Law of Genre," trans. Avital Ronell, Critical Inquiry 7, no. l (Autumn 1980): 57.

24. Christian Klein, "IV. Analyse biographischer Erzählungen," 199; "Kontext," 200-203; “'Histoire': Bestandteile der Handlung," 204-212; and Christian Klein and Matías Martínez, "Discours': Das 'Wie' der Erzählung - Darstellungsfragen," 213-219, all in Handbuch Biographie: Methoden, Traditionen, Theorien, ed. Christian Klein (Stuttgart: Metzler, 2009), 199-219.

25. See, for instance, Hayden White, "The Historical Text As Literary Artifact" [1978], in The History and Narrative Reader, ed. Geoffrey Roberts (London: Routledge, 2001), 221-236. 
26. Dorrit Cohn, The Distinction of Fiction (Baltimore: Johns Hopkins University Press, 1999), 112.

27. Cohn, The Distinction of Fiction, 114.

28. Cohn, The Distinction of Fiction, 112.

29. Cohn, The Distinction of Fiction, 15.

30. Cohn, The Distinction of Fiction, 15.

31. Cohn, The Distinction of Fiction, 35.

32. Cohn, The Distinction of Fiction, 26-30.

33. Ansgar Nünning, "Fiktionalität, Faktizität, Metafiktion," in Handbuch Biographie, ed. Klein (Stuttgart: Metzler, 2009), 26, my translation.

34. Dieter Kühn, Clara Schumann, Klavier: Ein Lebensbuch (Frankfurt am Main: S. Fischer, 1996), 289, my translation.

35. "Eins freilich hat in $(\mathrm{m})$ einer literarischen Biographie keinen Platz: Fiktion." Dieter Kühn, "Werkreflexion, Stichwort: literarische Biographie," in Grundlagen der Biographik: Theorie und Praxis des biographischen Schreibens, ed. Christian Klein (Stuttgart: Metzler, 2002), 184, my translation.

36. Lee Gutkind, The Art of Creative Nonfiction (New York: Wiley, 1997), 10.

37. Lara Feigel, The Bitter Taste of Victory: In the Ruins of the Reich (London: Bloomsbury, 2016), 106.

38. Gunnthorunn Gudmundsdottir, Borderlines: Autobiography and Fiction in Postmodern Life-Writing (Amsterdam: Rodopi, 2003), 4.

39. Ní Dhúill, "Towards an Antibiographical Archive," 286.

40. See Michael Lackey, "Locating and Defining the Bio in Biofiction," $a / b$ : Auto/Biography Studies 31, no. 1 (2016): 3, http://dx.doi.org/10.108 $0 / 08989575.2016 .1095583$. However, it must be noted that recently this criterion of the name has been called into question. For instance, Charlotte Boyce discusses Gaynor Arnold's After Such Kindness (2012) as an instance of "biofiction" though the book-clearly based on Charles Lutwidge Dodgson's now-famous attachment to Alice Liddell-changes the historical characters' names, while arguably inciting one to read the novel in the light of Lewis Carroll's biography. See Charlotte Boyce, "Who in the world am I?': Truth, Identity and Desire in Biofictional Representations of Lewis Carroll and Alice Liddell," in Neo-Victorian Biofiction, ed. Marie-Luise Kohlke and Christian Gutleben (Leiden: Brill Rodopi, 2017).

41. See, for example, Michael Lackey's introduction to Truthful Fictions: Conversations with American Biographical Novelists (New York: Bloomsbury, 2014). See also Martin Middeke, "Introduction," in Biofictions: The Rewriting of Romantic Lives in Contemporary Fiction and Drama, ed. Martin Middeke and Werner Huber (Rochester: Camden House, 1999), 1-25. 
42. Though they may have been known by different labels; in the context of her study on modernist writers, for instance, Hoberman speaks of "novelistic biographies." See Ruth Hoberman, Modernizing Lives: Experiments in English Biography, 1918-1939 (Carbondale: Southern Illinois University Press, 1987), 13.

43. Interestingly, the earlier Artemisia by Anna Banti-published in 1947 and far from being a postmodernist novel-is much more experimental in its structure, style, and reflections on the question and ethics of writing about a historical subject. See Lucia Boldrini, Autobiographies of Others: Historical Subjects and Literary Fiction (New York: Routledge, 2012), 149-168, for an extended discussion of Banti's novel as a "heterobiography."

44. Michael Lackey, The American Biographical Novel (New York: Bloomsbury, 2016), 14. See also the introduction to Biographical Fiction: A Reader (New York: Bloomsbury, 2017), which Lackey edited most recently.

45. Ina Schabert, In Quest of the Other Person: Fiction as Biography (Tübingen: Francke, 1990), 4.

46. Schabert, In Quest of the Other Person, 20-21 and 47.

47. Kacandes, "Experimental Life-Writing," 381-382.

48. John F. Keener, Biography and the Postmodern Historical Novel (Lewiston: Mellen, 2001), 1-2.

49. See, for instance, Max Saunders, "Life-Writing, Cultural Memory, and Literary Studies." Cultural Memory Studies: An International and Interdisciplinary Handbook, ed. Astrid Erll and Ansgar Nünning (Berlin: de Gruyter, 2008), 321-331. See also Astrid Erll and Ann Rigney, "Literature and the Production of Cultural Memory: Introduction," European Journal of English Studies 10, no. 2 (2006): 111-115, http:// dx.doi.org/10.1080/13825570600753394.

50. Jamie Doward and Mark Townsend, "Firebomb Attack on Book Publisher," Guardian, 28 September 2008, https://www.theguardian. com/uk/2008/sep/28/muhammad.book.attack.

51. Farzana Versey, "Who Says You Can't Write about Muhammad? How Liberal Fiction Dictators Play With History," State of Nature, 18 July 2008, http://www.stateofnature.org/?p=6416.

52. Anon. "Leeds United Legend Wins Apology from Author." Yorkshive Evening Post, 6 February 2008. http://www.yorkshireeveningpost. co.uk/news/leeds-united-legend-wins-apology-from-author-1-2170300.

53. Vreeland, Susan. The Passion of Artemisia. London: Review, 2002. Frontmatter.

54. Sarah Churchwell, The Many Lives of Marilyn Monroe (New York: Picador, 2004), 119. 
55. On 20 May 2015, Lucia Boldrini and Blake Morrison, both at Goldsmiths, University of London (which offers an MA explicitly called "in Creative and Life Writing"), co-organised the conference "Consent, Freedom and the Personal: Ethics in Creative Non-fiction," which focused on the difficult balance between the freedoms and responsibilities of writing creatively about others and about oneself and the legal, marketing, and academic research ethics contexts of such writing.

56. Philippe Lejeune, Le Pacte autobiographique (Paris: Seuil, 1975), 26.

57. See, for example, Christian Klein, "IV. Analyse biographischer Erzählungen," 199; Philippe Carrard, "Biography and the Representation of Consciousness," Narrative 5 (1997): 299-300. See also Kacandes, "Experimental Life Writing," 381. Kacandes uses Lejeune's influential definition of autobiography for her division of life-writing experiments into four basic categories: experiments with "time," "medium," "the relational," and the "focus" or topic of a work (Kacandes, "Experimental Life Writing," 383-388).

58. Cohn, The Distinction of Fiction, 35.

59. Life-Writing studies followed suit: in September 2013, the inaugural conference of the Oxford Centre for Life-Writing was entitled "The Lives of Objects."

60. Kacandes, "Experimental Life Writing," 387-388.

61. See Saunders's, Hannesschläger's, and Gudmundsdottir's chapters in this volume, respectively.

62. Thomas Jones, "Summertime by JM Coetzee," Guardian, 6 September 2009, https://www.theguardian.com/books/2009/sep/06/jm-coetzeesummertime.

63. Saunders, "Life-Writing, Cultural Memory, and Literary Studies," 329.

64. Lee, Biography, 3.

65. See Kilian's chapter in this volume.

66. See Palazzolo's chapter on Kay's memoir and autobiographical poetry in this volume.

67. Christian Klein, "Biographik zwischen Theorie und Praxis: Versuch einer Bestandsaufnahme," in Grundlagen der Biographik, 13.

68. Susanna Egan, Mirror Talk: Genres of Crisis in Contemporary Autobiography (Chapel Hill: University of North Carolina Press, 1999), 8.

69. See Max Saunders's chapter in this volume. Jan Alber would term this "unnatural narration." See, for instance, Jan Alber et al., "Introduction," in A Poetics of Unnatural Narrative, ed. Jan Alber, Henrik Skov Nielsen, and Brian Richardson (Columbus: The Ohio State University Press, 2013), 1-15. 
70. For a discussion of the different instances of "I" in autobiography, see Smith and Watson, Reading Autobiography, 71-76.

71. Cohn, The Distinction of Fiction, 125 and 18.

72. Boldrini, Autobiographies of Others, 2.

73. Boldrini, Autobiographies of Others, 6.

74. Stephen Moss, "Wainwright the Poisoner by Andrew Motion," Guardian, 1 March 2000, https://www.theguardian.com/books/2000/mar/01/ andrewmotion.

75. Joseph Fichtelberg, "Introduction," True Relations: Essays on Autobiography and the Postmodern, ed. Thomas Couser and Joseph Fichtelberg (Westport: Greenwood Press, 1998), 3.

76. See, for example, Max Saunders, Self Impression: Life-Writing, Autobiografiction, and the Forms of Modern Literature (Oxford: Oxford University Press, 2010), 7.

77. Kacandes "Experimental Life Writing," 384-385. See also Smith and Watson, Reading Autobiography, 4. The experimental Bob Dylan biopic I'm Not There (2007) constitutes a much-noted example of filmic lifewriting; a recent example of life-writing for performance is Kat Francois's one-woman spoken-word show Raising Lazarus, performed in October 2016 at London's Roundhouse. In this work, the author-performer traces her biographical quest for her ancestor Lazarus Francois and highlights the significance of his biography for her own life and cultural identity.

78. Werner Wolf introduces the term "covert intermediality" to refer to the indirect appearance of one medium (e.g. film) in another (e.g. literature), in which the former nevertheless "makes its presence felt by some traces discernible in the signification of the work in question." Werner Wolf, The Musicalization of Fiction: A Study in the Theory and History of Intermediality (Amsterdam: Rodopi, 1999), 44-45.

79. See Virginia Woolf, “The New Biography," 231-234.

80. This is not to say that we propose a conflation of biography and autobiography. Rather, we are following Kacandes's view of life-writing genres as essentially connected by their "common reference to the "real world" (Kacandes, "Experimental Life Writing," 380). Her view is supported by Cohn (The Distinction of Fiction, 30) and Gudmundsdottir (Borderlines, 3 ), both of whom regard autobiography a referential genre no less than biography, although they also draw attention to the complexity of that referentiality.

81. Bart Moore-Gilbert, Postcolonial Life-Writing: Culture, Politics, and SelfRepresentation (London: Routledge, 2009), xvii.

82. See, for instance, Evelyn J. Hinz, "Mimesis: The Dramatic Lineage of Auto/Biography," in Essays on Life-Writing: From Genre to Critical Practice, ed. Marlene Kadar (Toronto: University of Toronto Press, 1992), 195-212. 
83. Rachel Gutiérrez, "What Is a Feminist Biography?," in All Sides of the Subject: Women and Biography, ed. Teresa Iles (New York: Teachers College Press, 1992), 49.

\section{REFERENCES}

Alber, Jan, Stefan Iversen, Henrik Skov Nielsen, and Brian Richardson. "Introduction." In A Poetics of Unnatural Narrative, eds. Jan Alber, Henrik Skov Nielsen, and Brian Richardson, 1-15. Columbus: The Ohio State University Press, 2013.

Boldrini, Lucia. Autobiographies of Others: Historical Subjects and Literary Fiction. In Routledge Studies in Twentieth-Century Literature 26. New York: Routledge, 2012.

Bray, Joe, Alison Gibbons, and Brian McHale. "Introduction." In The Routledge Companion to Experimental Literature, eds. Joe Bray, Alison Gibbons, and Brian McHale, 1-18. London: Routledge, 2012.

Buchanan, Ian. "Avant-Garde.” In A Dictionary of Critical Theory. Oxford: Oxford University Press, 2010. http://www.oxfordreference.com/view/10.1093/ acref/9780199532919.001.0001/acref-9780199532919-e-59.

Carrard, Philippe. "Biography and the Representation of Consciousness." Narrative 5 (1997): 287-305.

Churchwell, Sarah. The Many Lives of Marilyn Monroe. New York: Picador, 2004. Cline, Sally, and Carole Angier. The Arvon Book of Life Writing: Writing Biography, Autobiography and Memoir. London: Methuen Drama, 2010.

Cohn, Dorrit. The Distinction of Fiction. Baltimore: Johns Hopkins University Press, 1999.

Colman, Andrew M. "Experiment." In A Dictionary of Psychology. Oxford: Oxford University Press, 2009. http://www.oxfordreference.com/view/10.1093/acref/9780199534067.001.0001/acref9780199534067-e-2946.

Derrida, Jacques. "The Law of Genre," trans. Avital Ronell. Critical Inquiry 7 (1) (Autumn 1980): 55-81.

Doward, Jamie, and Mark Townsend. "Firebomb Attack on Book Publisher." Guardian, September 28, 2008. https://www.theguardian.com/uk/2008/ sep/28/muhammad.book.attack.

Egan, Susanna. Mirror Talk: Genres of Crisis in Contemporary Autobiography. Chapel Hill: University of North Carolina Press, 1999.

Erll, Astrid, and Ann Rigney. "Literature and the Production of Cultural Memory: Introduction." European Journal of English Studies 10 (2) (2006): 111-115. doi:10.1080/13825570600753394.

Feigel, Lara. The Bitter Taste of Victory: In the Ruins of the Reich. London: Bloomsbury, 2016. 
Fichtelberg, Joseph. "Introduction.” In True Relations: Essays on Autobiography and the Postmodern, eds. Thomas Couser and Joseph Fichtelberg, 1-9. Westport: Greenwood Press, 1998.

Flood, Alison. "AS Byatt Wins $€ 150,000$ Erasmus Prize for 'Exceptional Contribution to Culture'." Guardian, January 18, 2016. https://www.theguardian.com/books/2016/jan/18/as-byatt-winserasmus-prize-award-contribution-culture.

Frow, John. Genre. The New Critical Idiom. London: Routledge, 2006.

Gilmore, Leigh. "The Mark of Autobiography: Postmodernism, Autobiography, and Genre." In Autobiography and Postmodernism, eds. Kathleen Ashley and Leigh Gilmore, 3-18. Amherst: The University of Massachusetts Press, 1994.

Gudmundsdottir, Gunnthorunn. Borderlines: Autobiography and Fiction in Postmodern Life Writing. Amsterdam: Rodopi, 2003.

Gutiérrez, Rachel. "What Is a Feminist Biography?" In All Sides of the Subject: Women and Biography, ed. Teresa Iles, 48-55. New York: Teachers College Press, 1994.

Gutkind, Lee. The Art of Creative Nonfiction. New York: Wiley, 1997.

Hadley, Louisa. Neo-Victorian Fiction and Historical Narrative. Basingstoke: Palgrave Macmillan, 2010.

Hinz, Evelyn J. "Mimesis: The Dramatic Lineage of Auto/Biography." In Essays on Life Writing: From Genre to Critical Practice, ed. Marlene Kadar, 195-212. Toronto: University of Toronto Press, 1992.

Hoberman, Ruth. Modernizing Lives: Experiments in English Biography, 19181939. Carbondale: Southern Illinois University Press, 1987.

Jones, Thomas. "Summertime by JM Coetzee." Guardian, September 6, 2009. https://www.theguardian.com/books/2009/sep/06/jm-coetzeesummertime.

Kacandes, Irene. "Experimental Life Writing." In The Routledge Companion to Experimental Literature, eds. Joe Bray, Alison Gibbons, and Brian McHale, 380-392. London: Routledge, 2012.

Keener, John F. Biography and the Postmodern Historical Novel. Lewiston: Mellen, 2001.

Klein, Christian. "Biographik zwischen Theorie und Praxis: Versuch einer Bestandsaufnahme." In Grundlagen der Biographik: Theorie und Praxis des biographischen Schreibens, ed. Christian Klein, 1-22. Stuttgart: Metzler, 2002.

Klein, Christian. “Histoire': Bestandteile der Handlung." In Handbuch Biographie: Methoden, Traditionen, Theorien, ed. Christian Klein, 204-212. Stuttgart: Metzler, 2009.

Klein, Christian. "Kontext." In Handbuch Biographie: Methoden, Traditionen, Theorien, ed. Christian Klein, 200-203. Stuttgart: Metzler, 2009. 
Klein, Christian. "IV. Analyse biographischer Erzählungen.” In Handbuch Biographie: Methoden, Traditionen, Theorien, ed. Christian Klein, 199. Stuttgart: Metzeler, 2009.

Klein, Christian, and Matías Martínez. “ 'Discours': Das 'Wie' der ErzählungDarstellungsfragen." In Handbuch Biographie: Methoden, Traditionen, Theorien, ed. Christian Klein, 213-219. Stuttgart: Metzler, 2009.

Kohlke, Marie-Luise, and Christian Gutleben (eds.). Neo-Victorian Biofiction. Leiden: Brill Rodopi, 2017.

Kühn, Dieter. Clara Schumann, Klavier: Ein Lebensbuch. Frankfurt am Main: S. Fischer, 1996.

Kühn, Dieter. "Werkreflexion, Stichwort: Literarische Biographie.” In Grundlagen der Biographik: Theorie und Praxis des biographischen Schreibens, ed. Christian Klein, 179-202. Stuttgart: Metzler, 2002.

Lackey, Michael. "Introduction: A Narrative Space of Its Own." In Biographical Fiction: A Reader, ed. Michael Lackey, 1-15. New York: Bloomsbury, 2017.

Lackey, Michael. "Locating and Defining the Bio in Biofiction." In a/b: Auto/ Biography Studies 31 (1) (2016): 3-10. doi:10.1080/08989575.2016.1095 583.

Lackey, Michael. The American Biographical Novel. New York: Bloomsbury, 2016.

Lackey, Michael. Truthful Fictions: Conversations with American Biographical Novelists. New York: Bloomsbury, 2014.

Leader, Zachary. "Introduction." In On Life-Writing, ed. Zachary Leader, 1-6. Oxford: Oxford University Press, 2015.

Lee, Hermione. Biography: A Very Short Introduction. Oxford: Oxford University Press, 2009.

"Leeds United Legend Wins Apology from Author." Yorkshire Evening Post, February 6, 2008. http://www.yorkshireeveningpost.co.uk/news/ leeds-united-legend-wins-apology-from-author-1-2170300.

Lejeune, Philippe. Le Pacte autobiographique. Paris: Seuil, 1975.

Matthews, Samantha. "Autobiography." Oxford Bibliographies, July 24, 2013. http://www.oxfordbibliographies.com/view/document/obo9780199799558/obo-9780199799558-0023.xml.

Middeke, Martin. "Introduction." In Biofictions: The Rewriting of Romantic Lives in Contemporary Fiction and Drama, eds. Martin Middeke, and Werner Huber, 1-25. Rochester: Camden House, 1999.

Moore-Gilbert, Bart. Postcolonial Life-Writing: Culture, Politics, and SelfRepresentation. London: Routledge, 2009.

Moss, Stephen. "Wainwright the Poisoner by Andrew Motion." Guardian, March 1, 2000. https://www.theguardian.com/books/2000/mar/01/ andrewmotion.

Ní Dhúill, Caitríona. “Towards an Antibiographical Archive: Mediations Between Life Writing and Metabiography." Life Writing 9 (3) (2012): 279-289. 
Nünning, Ansgar. “Fiktionalität, Faktizität, Metafiktion.” In Handbuch Biographie, ed. Christian Klein, 21-27. Stuttart: Metzler, 2009.

O'Brien, Sharon. "Feminist Theory and Literary Biography." In Contesting the Subject: Essays in the Postmodern Theory and Practice of Biography and Biographical Criticism, ed. William H. Epstein, 123-133. West Lafayette: Purdue University Press, 1991.

Reulecke, Anne-Kathrin. "'Die Nase der Lady Hester': Überlegungen zum Verhältnis von Biographie und Geschlechterdifferenz." Biographie als Geschichte, ed. Hedwig Röckelein, 117-142. Tübingen: Edition Diskord, 1993.

Ruse, Michael. "Experiment." In The Oxford Companion to Philosophy. Oxford: Oxford University Press, 2005. http://www.oxfordreference.com/view/ 10.1093/acref/9780199264797.001.0001/acref-9780199264797-e-836.

Saunders, Edward. "Defining Metabiography in Historical Perspective: Between Biomyths and Documentary." Biography 38 (3) (2015): 325-342.

Saunders, Max. "Life-Writing, Cultural Memory, and Literary Studies." In Cultural Memory Studies: An International and Interdisciplinary Handbook, eds. Astrid Erll, and Ansgar Nünning, 321-331. Berlin: de Gruyter, 2008.

Saunders, Max. Self Impression: Life-Writing, Autobiografiction, and the Forms of Modern Literature. Oxford: Oxford University Press, 2010.

Schabert, Ina. In Quest of the Other Person: Fiction as Biography. Tübingen: Francke, 1990.

Schlaeger, Jürgen. "Biography: Cult as Culture.” In The Art of Literary Biography, ed. John Batchelor, 57-71. Oxford: Clarendon Press, 1995.

Smith, Sidonie, and Julia Watson. Reading Autobiography: A Guide for Interpreting Life Narratives. Minneapolis: University of Minnesota Press, 2010.

Stanley, Liz. The Auto/Biographical I: The Theory and Practice of Feminist Auto/ Biography. Manchester: Manchester University Press, 1992.

Stannard, Martin. "The Necrophiliac Art?” In The Literary Biography: Problems and Solutions, ed. Dale Salwak, 32-40. Basingstoke: Macmillan, 1996.

Versey, Farzana. "Who Says You Can’t Write about Muhammad? How Liberal Fiction Dictators Play With History." State of Nature, July 18, 2008. http:// www.stateofnature.org/? $\mathrm{p}=6416$.

Vreeland, Susan. The Passion of Artemisia. London: Review, 2002.

White, Hayden. "The Historical Text as Literary Artifact" [1978]. In The History and Narrative Reader, ed. Geoffrey Roberts, 221-236. London: Routledge, 2001.

Wolf, Werner. The Musicalization of Fiction: A Study in the Theory and History of Intermediality. Amsterdam: Rodopi, 1999.

Woolf, Virginia. "The New Biography." In Collected Essays, vol. IV, 229-235. London: The Hogarth Press, 1967. 


\section{Author Biography}

Julia Novak is a lecturer at the University of Salzburg and a Marie Andessner Visiting Research Fellow at the Centre for Life-Writing Research, King's College London. She has published extensively on biofiction and is currently working on a book project on biographical novels about famous historical women artists. She has also written a book on reading groups, Gemeinsam Lesen (Lit, 2007), and a book entitled Live Poetry: An Integrated Approach to Poetry in Performance (Rodopi, 2011). www.julianovak.at.

Open Access This chapter is licensed under the terms of the Creative Commons Attribution 4.0 International License (http://creativecommons.org/licenses/ by $/ 4.0 /$ ), which permits use, sharing, adaptation, distribution and reproduction in any medium or format, as long as you give appropriate credit to the original author(s) and the source, provide a link to the Creative Commons license and indicate if changes were made.

The images or other third party material in this chapter are included in the chapter's Creative Commons license, unless indicated otherwise in a credit line to the material. If material is not included in the chapter's Creative Commons license and your intended use is not permitted by statutory regulation or exceeds the permitted use, you will need to obtain permission directly from the copyright holder.

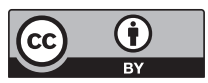

